\title{
Article
}

Oonagh B. Breen*

\section{The European Foundation Statute Proposal: Striking the Balance between Supervising and Supporting European Philanthropy?}

\begin{abstract}
This article examines the Commission's Proposal for a Council Regulation on the Statute for a European Foundation (Fundatio Europaea). Focusing on the proposed transparency and accountability provisions, it interrogates whether these provisions are sufficiently robust to facilitate effective Member State supervision of this proposed new supranational legal form, given identified weaknesses in existing Member State foundation regulatory regimes. Consideration is also given to the Statute's proposed reporting and auditing mechanisms. Particular attention is paid to the challenges inherent in standardising financial reporting standards and the missed opportunities to introduce best practice in the draft Regulation. The article concludes by identifying a number of interpretative loopholes in the existing proposal, which if adopted in its current format, would weaken the potential for an effective, efficient and feasible solution to the problems currently experienced by many foundations operating on a cross-border basis in Europe.
\end{abstract}

Keywords: philanthropy, European Foundation Statute, transparency, accountability, financial reporting standards, member state supervision, mutual recognition, competent authority, public benefit purpose, tax equivalency

*Corresponding author: Oonagh B. Breen, School of Law, University College Dublin, Belfield, Dublin 4, Ireland, E-mail: oonagh.breen@ucd.ie

\section{Introduction}

According to a 2009 European Commission Feasibility Study on a European Foundation Statute (EFS), an astonishingly high percentage of foundations 
based in the EU (in the region of $67 \%$ ) engage in international activities. ${ }^{1}$ Although doubts remain over the empirical reliability of the data, ${ }^{2}$ the general trend towards increasing cross-border activities of national foundations in Europe is indisputable. With approximately 110,000 foundations in Europe holding assets in excess of $€ 1,000 \mathrm{bn}$ and estimated annual expenditure in the region of $€ 153 \mathrm{bn},{ }^{3}$ the economic importance of the sector outstrips that of the US foundation sector. ${ }^{4}$ Notwithstanding its scale, foundations wishing to operate in more than one European Member State have faced legal and regulatory difficulties when it comes to establishment, registration and operation in other Member States from both a civil law and a tax law perspective. Apart from adversely affecting philanthropic activity, the associated legal costs of these legal barriers to foundations are substantial and estimated to cost foundations between $€ 101 \mathrm{~m}$ and $€ 178 \mathrm{~m}$ per annum. ${ }^{5}$

Concerted efforts by a number of stakeholders over the past decade have made headway in dismantling existing obstacles to free movement of philanthropy. ${ }^{6}$ The European Court of Justice's growing jurisprudence has affirmed that the right of free movement of capital extends to non-profit entities. ${ }^{7}$ The Court, spurred on by an active European Commission, has also prohibited tax discrimination between charities based on whether the donor/recipient is domestic or foreign based. ${ }^{8}$ As a result of Commission infringement actions since 2005, 26 cases have been successfully closed due to changes in Member

1 University of Heidelberg, Centre for Social Investment, Feasibility Study on a European Foundation Statute - Final Report (2009) at 149 available at http://ec.europa.eu/internal_market/company/docs/eufoundation/feasibilitystudy_en.pdf (last accessed March 11, 2013), hereinafter "Feasibility Study".

2 Ibid, at 150-2.

3 Ibid, at 18.

4 Ibid, at 2.

5 Ibid, at 178 .

6 The EU is founded upon a series of fundamental freedoms laid down in the Treaty of Rome, namely free movement of workers, free movement of goods, free movement of capital and freedom of establishment, thereby creating a common market between European Member States in which goods, services and people flow freely, uninhibited by country barriers. The term "free movement of philanthropy" is used in this vein to express the aspiration of inter-state free movement of charitable donations and activities unencumbered by legal or taxation barriers.

7 See Case C-386/04, Centro di Musicologia Walter Stauffer v. Finanzamt München für Körperschaften, [2006] ECR I-8203.

8 Case C-318/07 Hein Persche v. Finanzamt Lüdenscheid, [2009] ECR I-359; Case C-25/10 Missionswerk Werner Heukelbach eV v Belgium [2011] 2 C.M.L.R. 35; Case C-10/10 Re Taxation of Gifts to Research and Teaching Institutions: European Commission v Austria [2011] 3 C.M.L.R. 26. 
State legislation, eliminating discriminatory tax treatment. ${ }^{9}$ Private initiatives, in the form of the Transnational Giving Europe Network, have also sought to assist donors in making tax efficient charitable donations to foreign charities. Established in 1999 and covering 15 European countries, the TGE network assisted more than 6,200 donors to channel $€ 7$ million to chosen charities across Europe in 2012. ${ }^{10}$ Notwithstanding all of these initiatives, foundations across Europe have long called for the creation of a supranational legal form for public benefit foundations to enable them to operate seamlessly throughout the European Union. ${ }^{11}$

In February 2012, the European Commission published its proposal for a Council Regulation for a EFS ${ }^{12}$ which, if adopted, will establish a new European legal structure for certain public benefit organisations. Use of this new European form would enable foundations and other incorporated public benefit organisations (but not charitable trusts) to operate uniformly across EU Member States in a recognisable form, thereby dispensing with separate national legal and administrative establishment requirements and barriers to operation. Additionally, European Foundations (FEs) would benefit from automatic non-discriminatory tax treatment in each Member State: FEs would receive the same tax exemptions as domestic public benefit purpose entities/foundations and donations to FEs would be treated for tax purposes identically to donations to national public benefit purpose entities/foundations in that Member State.

In common with existing European vehicles such as the European Economic Interest Group (EEIG), ${ }^{13}$ the European Company $(\mathrm{SE})^{14}$ and the European

9 F. Liberatore, (2012). "Tax Aspects of the Commission's Proposal for a European Foundation Statute," presented at ERA, A New Legal Form for European Philanthropy: The Commission's Proposal for a European Foundation (FE) Statute, Brussels, October 30-31.

10 See http://www.transnationalgiving.eu/tge/default.aspx?id=219948\&langtype=1033 (last accessed March 21, 2013).

11 See European Commission, DG for Internal Market and Services, Report on Consultation and Hearing on Future Priorities for the Action Plan on Modernising Company Law and Enhancing Corporate Governance in the European Union (2006) at 26. Available at http://ec.europa.eu/ internal_market/company/docs/consultation/final_report_en.pdf; European Foundation Centre 18th Annual General Assembly (AGA) and Conference, Why is a European statute for foundations needed?, Madrid, June 1st-3rd 2007; University of Heidelberg, Feasibility Study (2009), supra n. 1; European Foundation Centre, It's Time for a European Statute, (2012a) available at http:// www.efc.be/programmes_services/resources/Documents/EFS_brochure_2012_FINAL.pdf (last accessed March 21, 2013).

12 Proposal for a Council Regulation on the Statute for a European Foundation (FE), COM(2012) 35 final.

13 Regulation (EEC) No. 2137/85 on the European Economic Interest Grouping (EEIG) O.J. 1985 L 199/1. 14 Regulation (EC) No. 2157/2001 on the Statute for a European Company (SE), O.J. 2001, L 294/1. 
Cooperative Society (SCE), ${ }^{15}$ the success or failure of the Commission's proposal $^{16}$ will hinge on the scope of the proposed Regulation's application (i.e. clear identification of the entities that can avail of the EFS); the advantages associated with this optional instrument encouraging its adoption (whether couched in terms of establishment rights, foreign civil or per se tax recognition as opposed to tax equivalency recognition); and the degree to which the new entity is viewed by relevant stakeholders as accountable and transparent. Whereas there has been much discussion of the need for such a legal vehicle and its likely associated benefits, ${ }^{17}$ little has been written about the proposals for cross-border supervision and the standard of the accountability built into the Commission's proposal. $^{18}$ These latter elements form the focus of this article.

Section 2 outlines briefly the European meaning of the term "foundation" and compares it with its American counterpart. Section 3 considers the context for European regulation of NGO accountability and the challenges of developing an EU accountability framework for FEs in the absence of full harmonisation. Section 4 compares the individual powers to be bestowed on national supervisory authorities with existing national powers. Section 5 examines the proposed reporting and auditing requirements. In light of evolving international financial reporting standards (IFRS), it focuses on additional challenges facing policymakers and non-profits. Section 6 concludes by identifying specific areas in the Regulation open to interpretative difficulties, suggesting how these may be tackled in advance of adoption.

\section{American and European foundations - comparing like with like?}

From a US perspective, the European definition of a foundation will appear amorphous, overly broad and lacking the functional precision which one associates with the American foundation. In the United States, the Tax Reform Act

15 Regulation (EC) No. 1435/2003 on the Statute for a European Cooperative Society (SCE), O.J. 2003 L 207/1.

16 Cited supra, n. 12.

17 Salole, "Why is the European Foundation Statute Needed?", (2008)11(1) International Journal for Not-for-Profit Law, 75-84; MacDonald and Tayart de Borms, (eds.) Philanthropy in Europe: A Rich Past, A Promising Future (Alliance Publishing Trust (2008); European Foundation Centre, It's time for a European Foundation Statute (Brussels, 2012b).

18 C.f. Breen, "EU Regulation of Charitable Organizations: The Politics of Legally Enabling Civil Society” (2008) 10(3) International Journal for Not-for-Profit Law, 50-78. 
1969 negatively defines a foundation as a sub-category of tax-exempt charities that is neither a public charity nor a supporting organisation. ${ }^{19}$ This functional definition focuses on the foundation's predominant source of income. A foundation is classed as a charitable private foundation, if it receives most of its income from non-public sources and is considered to be donor controlled. The vast majority of private foundations in the US are grant-making foundations (95\%) with only $5 \%$ acting as operating foundations. ${ }^{20}$ There is a large degree of asset concentration amongst a small group of foundations at the top and the areas of human services, education, health and the arts attract the biggest grant shares. $^{21}$

These latter characteristics find echoes in Europe in terms of both asset concentration and popular grant recipient categories but the similarities tend to end there. No uniform legal definition of "foundation" exists in Europe. In contrast to the IRS functional definition, European civil law Member States take an organisational approach to foundations, eschewing functional criteria relating to funding source. Typically, a foundation consists of a specific legal form based on similar conceptual criteria that co-exists alongside other legal forms such as the non-profit association, corporation or cooperative. Even as between civil law Member States the definition of foundation will vary: from the high demands of French foundation law (which requires a foundation to have a public benefit purpose, minimum initial endowment of usually $€ 1,000,000$, and strong monitoring by the State supervisory authority) to the more liberal definition used in the Netherlands (where a foundation can pursue any lawful purpose, with no minimum initial endowment required, subject only to rudimentary control by the public attorney as the State supervisory authority, and with largely unconstrained economic activities). ${ }^{22}$ Common law Member States within the EU have an even more nebulous relationship with the term "foundation" where the term is used as a descriptive label more so than as an indication of legal form, funding source, tax designation or ultimate purpose.

Acknowledging these variances in its preliminary work on the EFS, the European Feasibility Study developed a "lowest-common-denominator" legal definition for a foundation. According to the Study, a foundation:

19 US Tax Code at 26 U.S.C. § 509 and section 501(c)(3).

20 Source: The National Center for Charitable Statistics at the Urban Institute available at http://nccsweb.urban.org/tablewiz/pf.php (last accessed July 29, 2013).

21 The Foundation Center Statistical Information Service, Distribution of Foundation Grants by Subject Categories, circa 2011, available at http:/foundationcenter.org/findfunders/statistics/ pdf/04_fund_sub/2011/10_11.pdf (last accessed July 30, 2013).

22 See Feasibility Study, supra, n. 1 at 13. 
- is an independent organisation (generally with its own legal personality), which has no formal membership,

- is supervised by a State supervisory authority, and

- serves a public benefit purpose (in some Member States: any lawful purpose), for which a founder has provided an endowment and determined the foundation's purpose and statutes. ${ }^{23}$

The Study further adapted this definition for use in EU common law jurisdictions to count as foundations those charities (regardless of their legal form) that make grants. ${ }^{24}$ What emerges from the research data available on foundations active in Europe is that a large share of the sector are operating foundations and thus have access to a substantial revenue stream. Moreover, in contrast to the United States, close ties often exist between government and foundations in Europe, resulting in the latter receiving substantial transfer payments from public budgets in return for their services. This development differs from the American experience of the historical emergence and growth of foundations as institution builders and policy interveners in an era of government incapacity and/or underdevelopment. From a US perspective, the European definition would thus include many "non" foundations, ${ }^{25}$ that is, operating foundations active in areas such as social welfare, health or education which in the US would be classed as public charities, hospitals or educational institutions (and not as private foundations) under discrete provisions of the US Tax Code.

\section{The context for European NGO accountability}

Calls for greater transparency and accountability on the part of European nonprofit entities, including public benefit foundations, are not new. The past decade has seen an increased EU level interest in and a greater emphasis on the need for non-profit accountability. Recent catalysts for such reform have ranged from fears over potential vulnerabilities of non-profits to terrorist financing abuse; ${ }^{26}$ to recognition that enhanced governance standards not only clamp

23 See Feasibility Study, supra, n. 1 at 45.

24 This adaption was based on prior research by the Charities Aid Foundation. See further, CAF, Grant-making by UK trusts and charities, January 2007, p. 3-4.

25 See Feasibility Study, supra, n. 1 at 40.

26 FATF Special Recommendation VIII; Commission Communication "The Prevention of and fight against terrorist financing through enhanced national level coordination and greater transparency of the non-profit sector: Recommendations for Member States and a framework for a code of conduct for NPOs to enhance transparency and accountability in the non-profit sector to prevent terrorist financing and other types of criminal abuse”, COM (2005) 620 final. 
down on rogue charities' activities but actually enable law-abiding charities to better achieve their charitable mission; ${ }^{27}$ and to the emergence of an informed understanding that better articulation of transparency and accountability standards at a national level can provide a solid basis for the growth of public benefit organisations for the betterment of civil society. ${ }^{28}$ In this latter instance, the focus of scrutiny is almost less on the NGO and more so on whether the Member State is compliant in providing a non-hostile environment for the encouragement of such public benefit bodies. ${ }^{29}$ At national level, much time and effort has been spent strengthening non-profit accountability in recent years. The 2009 European Centre for Not-for-Profit Law Study identified more than 140 national public and non-statutory schemes in force throughout the EU aimed at increasing accountability. ${ }^{30}$ Thus, it might safely be said that while there is a general consensus shared amongst Member States as to the importance of transparency and accountability there is no clear agreement on the optimum form or level that such accountability should take.

The proposal for an EFS feeds into this process by requiring FEs to be both accountable and transparent. Under the proposal, FEs would be directly accountable to the relevant national registry and supervisory authority. This accountability would extend to tax authorities through the supervisory authorities' sharing of information and intelligence. There is provision for further indirect accountability to the European Commission (via the national registry), and the

27 Matrix Insight, Study to Assess the Extent of Abuse of Non-Profit Organisations for Financial Criminal Purposes at EU Level, European Commission, Dg Justice, Freedom And Security 8 (Apr. 3, 2008) available at http://ec.europa.eu/homeaffairs/doc_centre/terrorism/docs/study_abuse_ non_profit_orgs_for_financial_criminal_purposes_avril09.pdf; European Centre for Not-forProfit Law [ECNL], Study on the Recent Public and Self-Regulatory Initiatives Improving Transparency and Accountability of Non-Profit Organisations in the European Union, at 94 (2009) [hereinafter ECNL Study], available at http://ecnl.org/dindocuments/306_ECNL\% 20Accountability\%20Study_published\%20on\%20DG\%20JLS.pdf; European Foundation Centre (EFC) and Donors and Foundations Networks in Europe (DAFNE), Exploring Transparency and Accountability Regulation of Public-Benefit Foundations in Europe (2011) [hereinafter, EFC/ DAFNE Report].

28 Council of Europe, Recommendation CM/Rec(2007)14 on the Legal Status of Nonprofit Organisations. Creation of Expert Council on NGO Law (2008) to monitor Member State compliance with the recommendations.

29 See, for example, Opinion on Amendments in 2009 to the NGO Law in Azerbaijan and their Application, Opinion prepared by Mr Jeremy McBride on behalf of the Expert Council at the request of the Standing Committee of the Conference of INGOs available at http://www.coe.int/ t/ngo/Source/OING_CONF_EXP_2011_2_opinion_NGO_law_Azerbijan_en.pdf (last accessed February 5, 2013).

30 ECNL Study, supra n. 27. 
Regulation's express emphasis on public disclosure ${ }^{31}$ might also be seen as a way of empowering the general public (be they donor, creditor or other interested party) to take some responsibility for scrutinising interaction with these entities.

What is perhaps less clear is the nature of the intended FE accountability that is, whether the regulation of this new European form will focus solely on investigating malfeasance or whether it will extend to the prosecution of operational inefficiencies by FEs. Although policymakers may have eschewed a harmonised approach to the European regulation of FEs, successful operation of the EFS will require some consensus on the level of FE failure that can be tolerated and a collective notion of the factors that might trigger Supervisory Authority action in a given Member State. Such consensus would be necessary to ensure even-handed cooperation amongst Supervisory Authorities under Article 47 of the proposed Regulation and to avoid forum shopping. Given the size and diversity of the FE sector and the various national supervisory regimes under which they operate, a shared understanding of the parameters of accountability is important.

In all cases in which accountability is sought, whether for Supervisory Authority action, tax authority information or stakeholder disclosure purposes, there is a related need for sufficient transparency based on reliable information to facilitate effective judgement calls. Whether the interested party is the Supervisory Authority, another state or foreign agency or a potential donor, for transparency to work (and thereby enable effective accountability), it is essential that the same information about the same matters be presented in a similar fashion. Without such ready comparability, it is hard to envisage how the EFS will achieve its goal of ensuring that the FE is perceived throughout the EU as a trustworthy and credible force.

So, at the outset, two issues of concern arise, namely, the scope of accountability (so that similar parameters of accountability are developed in each Member State) and the nature of the transparency underpinning this accountability. There are inherent challenges in creating a new legal form recognisable upon establishment in all Member States with liberty to operate on an inter-State basis without having first to prove equivalency under the national laws of a host Member State. To work, one could either drop accountability standards to the lowest-common-denominator (in a race to the bottom) or require those states with more lax approaches to accountability to raise their national standards in line with the dictates of more demanding neighbours (a type of back-door harmonisation).

31 Art 4(1) EFS, supra n. 12. 
The European Company Statute adopted the former lowest-commondenominator approach in the creation of the SE, leaving many regulatory issues within the control of national law. This led to difficulties in its implementation and a lower than expected take-up. ${ }^{32}$ Proponents of the EFS claim that the EFS, in setting prescribed standards for FEs, avoids the pitfalls of the European Company Statute. To this end, the proposed Regulation sets out a number of minimum supervisory powers for all national authorities. Uncertainties exist as to how the exercise of these minimum powers will sit with national supervisory powers; particularly as to whether the proposed EFS standards will be sufficiently robust to overcome the otherwise wide discretion enjoyed by national laws in the regulation of foundations.

\section{Supervision and supervisory authorities}

According to the proposed EFS, the key to accountability will lie in cooperative subsidiarity underpinned by uniform minimum supervisory powers. In the words of the Preamble:

The Regulation should set minimum but strong supervisory powers to guarantee adequate and sufficiently uniform powers for supervisory authorities across the Union. For the sake of efficient supervision, cooperation between supervisory authorities of Member States should be ensured. ${ }^{33}$

To this end, the Regulation envisages the designation by each Member State of a "Supervisory Authority" (Article 45) and a national registry (Article 22), which will be notified to the Commission. ${ }^{34}$ Although the Regulation treats the Supervisory Authority and national registry as separate agencies, in practice many Member States (e.g. Bulgaria, Finland, Greece, and Slovakia) use one body for both purposes when it comes to the regulation of national foundations and this is likely to continue even if the proposed Regulation is adopted.

By its nature, the FE is designed to operate transnationally. Article 6 requires FEs to have activities or a statutory objective of carrying out activities

32 Lars Hammer-Jespersen, The FE in light of the development of European Company Law: lessons from the SE, SCE and SPE, delivered at the ERA Conference, "A New Legal form for European Philanthropy", Brussels, October 30-31, 2012.

33 See n. 12 supra, at [19].

34 The proposed Regulation, however, is silent as to which DG in the Commission should be notified and its subsequent duties upon receipt of information from national registries or supervisory authorities. 
in at least two Member States at the time of registration. ${ }^{35}$ As to which national laws apply and which Supervisory Authority is competent in respect of a particular FE, the proposed Regulation departs from the practice of the European Company Statute, which applied the real seat principle. ${ }^{36}$ Under the real seat principle, the governing laws were determined according to the location of the entity's principal establishment - that is, where the entity's decisions were made or affairs managed. In contrast, and following more recent ECJ jurisprudence on the matter, ${ }^{37}$ the EFS Regulation views the competent Supervisory Authority and applicable national laws to be those of the Member State in which the FE is registered (Article 45), hereinafter referred to as the "home Member State". This change has significant implications for the exercise of supervisory powers under Article 46 and for both supervisory cooperation (Article 47) and tax authority notification (Article 48). Real seat jurisdictions ${ }^{38}$ are unlikely to be happy with this move, one fear being that it may be more difficult to have good fiscal control information if a lack of transparency flows from the splitting of place of registration from place of principal establishment. ${ }^{39}$ To this end, in its draft interim report, issued in March 2013, the European Parliament Committee on Legal Affairs recommended that the proposal be amended to ensure that the registered seat and the central administration of

35 An amendment requiring the FE to maintain these objectives beyond the date of registration for the duration of the entity's existence would seem to be advisable in keeping the use of the FE in line with the proposed Regulation's intentions.

36 Regulation No. 2157/2001, supra n. 14, Art. 7.

37 Case C-212/97, Centros Ltd v Erhvervs-og Selskabsstyrelsen [1999] ECR I-1459; Case 208/00, Uberseering BV v Nordic Construction Co Baumanagement GmbH (NCC) [2002] ECR I-9919; and Case C-167/01, Kamer van Koophandel en Fabrieken voor Amsterdam v Inspire Art [2003] E.C.R. I10155. It is notable that this case law was all decided in the context of for-profit corporations, and the ECJ has not yet had an opportunity to make a ruling on its application to non-profit foundations.

38 Belgium, France, Luxembourg, Austria, Portugal and Italy all apply the real seat theory see Kilian Baelz and Teresa Baldwin, "The End of the Real Seat Theory (Sitztheorie): the European Court of Justice Decision in Ueberseering of 5 November 2002 and its Impact on German and European Company Law," 3 German Law Journal (2002), available at http://www. germanlawjournal.com/index.php?pageID=11\&artID=214

39 A similar fear has been voiced by some Member State and trade union stakeholders in the Commission's Report on the European Company Statute. Notwithstanding these criticisms, the Report supports this change in the SE statute. See Commission, The application of Council Regulation 2157/2001 of 8 October 2001 on the Statute for a European Company (SE), COM(2010) 676 final, at 8 and Commission, Public Consultation on the Cross-border Transfers of Registered Offices of Companies, January 14, 2013 available at http://ec.europa.eu/internal_market/consultations/2013/seat-transfer/index_en.htm (accessed March 25, 2013). 
the FE be in the same Member State in order to facilitate supervisory authority supervision. ${ }^{40}$

Let us, thus, first examine the powers available to supervisory authorities under the Regulation before considering the practical application of these comity arrangements.

\subsection{Powers and duties of the supervisory authority}

The main powers of the Supervisory Authority are set out in Article 46 of the proposed Regulation. Primarily, the Authority must ensure that the FE's governing board acts in accordance with the statutes of the FE, the EFS Regulation and with applicable national law of the home Member State (Article 46(1)). The Supervisory Authority is perceived as having a proactive watching brief over the activities of the FE. It is envisaged as playing an important role in the overall lifecycle of the FE through its receipt (and presumably, review) of the FE's annual accounts and report on its activities (Article 34); the need for its approval should an FE wish to change its public benefit purposes (Article 20(4)); and its ability to seek to wind up or to petition a competent court to wind up an FE in accordance with Article 43(1). The Supervisory Authority, however, has no power to act in the administration of the FE (Article 46(3)).

In addition to involvement at these life-changing events, Article 46 provides that all supervisory authorities should have certain specified powers in respect of FEs registered in their home Member State. These powers are viewed as minimum powers and may be further supplemented or expanded under applicable national law:

\subsubsection{Power of investigation: scope}

In a case where the Supervisory Authority has reasonable grounds to believe that the FE's governing board is not acting in accordance with the FE's statutes, the EFS or with the applicable national law of the home Member State, the Supervisory Authority can inquire into the FE's affairs and require its directors and employees along with its auditor(s) to make available all necessary information and evidence (Article 46(2)(a)).

The EFS offers no clarification as to when a Supervisory Authority might form a reasonable suspicion regarding the conduct of the FE. Arguably, three

40 European Parliament Committee on Legal Affairs, Draft Interim Report on the proposal for a Council regulation on the Statute for a European Foundation (FE), 2012/0022 (APP), March 4, 2013a. The European Parliament endorsed this proposal in its resolution on the proposal for a Council regulation on the Statute for a European Foundation on July 2, 2013. 
possibilities arise. First, the Supervisory Authority, as a direct recipient of FE annual reports and accounts (Article 34(2)), could engage in proactive scrutiny and investigation, where appropriate. Second, the Supervisory Authority in a Member State in which an FE carries out its activities (hereinafter referred to as the "host Member State") may have concerns or suspicions about an FE's conduct or its public benefit activities. Article 47 empowers such a Supervisory Authority to request the Supervisory Authority in the home Member State to undertake an Article 46 investigation. If so requested, the home Supervisory Authority is mandated to investigate (Article 47(3)). Alternatively, the national registry in the home Member State could actively review FE annual reports and accounts and could then refer cases requiring further investigation to the Supervisory Authority (bearing in mind that in some Member States, the Supervisory Authority and the national registry are one and the same).

However, it ultimately becomes seized of the case, upon commencing investigations into an FE under Article 46(2)(a), the Supervisory Authority of the home Member State must inform its national tax authority and keep it informed on the progress and outcome of those inquiries as well as any warnings issued or sanctions imposed (Article 48).

\subsubsection{Practical implications}

The current capacity of existing national supervisory authorities to scrutinise annual reports and accounts of national foundations varies. In part, this may be caused by multiple state agency involvement in the supervision of national foundations - with oversight often spread between a national registry, the tax office, one or more ministerial departments, the public prosecutor and the district court - thereby resulting in under-accountability.

A review of the EU Member States' regulatory practices, as outlined by the European Foundation Centre (EFC), reveals a number of Member State supervisory authorities that are not actively engaged in the regular oversight of foundation activities or accounts. This may be because the national law does not empower the Supervisory Authority to carry out such scrutiny. For example, the EFC's Cypriot Rapporteur notes that, "the relevant legislation [in Cyprus] does not provide for any regulatory or supervisory control of foundations." ${ }^{41}$ Similarly, in Belgium, the EFC Rapporteur comments that:

41 See http://www.efc.be/programmes_services/resources/Documents/cyprus.pdf, at 9 (last accessed February 4, 2013). 
the extent of the supervision is quite limited. There are no ex officio inspections, reviews of reports, or inquiries. The Court can only take action in specific circumstances, upon a request introduced by the public prosecutor or by a director of the foundation, by its board of directors, or by any interested party. ${ }^{42}$

In other instances, it may simply be a case of inanition on the part of the regulator rather than lack of statutory competence. Thus, the EFC's Czech Rapporteur reports that notwithstanding the "combination of strict regulation, internal supervision, court supervision and tax authority supervision... [we] do not believe that enquiries are made or that public benefit organisations are subject to inspection." 43 And again, the Luxembourg EFC profile provides that "in practice there seems to be hardly any active supervision other than to check whether annual accounts are filed." 44

Other Member States seem to put forward a more rigorous regulatory regime for national foundations. Again, drawing on EFC legal and fiscal profiles, ${ }^{45}$ more active scrutiny is indicated on the part of supervisory authorities in Malta, Slovakia, Finland and France, although it is difficult to discern whether availability of a power to investigate, review or monitor implies frequent deployment of same. This patchwork approach to enforcement and indeed regulatory capacity, while acceptable at a national level in the regulation of national foundations may prove less than satisfactory in the oversight of FEs, particularly in the context of Member State Supervisory Authority cooperation. Clarification is, thus, called for here as to the triggers for supervisory intervention or investigation.

One interesting omission in the proposed EFS is the absence of any provision enabling the Supervisory Authority to accept third-party complaints or deal with whistleblowers. Under the proposed Regulation, the Supervisory Authority is obliged only to liaise with Member State tax authorities and the supervisory authorities of other Member States. Provision of such a third-party complaint mechanism would, arguably, support the Supervisory Authority in the exercise

42 See http://www.efc.be/programmes_services/resources/Documents/belgium.pdf, at 9 (last accessed February 4, 2013).

43 See http://www.efc.be/programmes_services/resources/Documents/czechrepublic.pdf, at 17 (last accessed February 4, 2013).

44 See http://www.efc.be/programmes_services/resources/Documents/luxembourg.pdf, at 7 (last accessed February 4, 2013).

45 Accessible at http://www.efc.be/programmes_services/resources/Pages/Legal-and-fiscalcountry-profiles.aspx (last accessed February 5, 2013). 
of its other Article 46 powers, ${ }^{46}$ and its inclusion in the next draft of the EFS should be seriously considered.

\subsubsection{Power to appoint an independent expert/examiner}

Where there is evidence of financial impropriety, serious mismanagement or abuse, the Supervisory Authority may appoint an independent expert to inquire into the affairs of the FE at the expense of the FE (Article 46(2)(b). Again, Article 48 requires the Supervisory Authority of the home Member State to inform its national tax authority, if it exercises its powers under this provision.

No further details or guidelines are provided as to the nature of the independent expert who may be appointed or as to his/her requisite qualifications. This provision again has many parallels at national level. The national laws of Slovenia and Austria allow the respective supervisory authorities to appoint an auditor in such circumstances. ${ }^{47}$ In England and Wales, the Charity Commission has power under s.76 of the Charities Act 2011 to appoint an interim manager of a charity where there is evidence of misconduct or mismanagement of charity. A similar provision exists under German law. ${ }^{48}$ In the Netherlands, external auditors charged with investigating the foundation and reporting to court are provided for. In Ireland, when commenced, the Charities Act 2009, s.64 will allow for the appointment of an inspector to investigate the affairs of a charity and to report to the national Supervisory Authority.

\subsubsection{Power to issue warnings}

Where there is evidence that the governing board has not acted in accordance with FE statutes, the EFS Regulation or applicable national law, the Supervisory Authority can issue warnings to the board or order it to comply with its statutes,

46 Complaints could form the basis for Article 46 investigations while still falling short of a third-party direct right of action against the FE. Third parties generally do not have statutory rights against foundations under national law unless they arise under contract law in the context of donors/creditors or employees. The possibility for direct third-party intervention varies thereafter since often the supervisory authority enjoys locus standi to protect the public interest. See, e.g., Irish Charities Act 1961, s.51, English Charities Act 2011, s.115 (providing for relator proceedings). In Sweden, it is possible for an interested party to sue foundation directors directly if by violating foundation law the director has caused the third-party loss - Hopt, Walz, von Hippel, and Then (eds), The European Foundation: A New Legal Approach, (Cambridge, 2006), p. 127.

47 Hopt et al., supra, n. 46, at 173.

48 Ibid, at 173. 
the Regulation or national law, respectively. How the Supervisory Authority comes by this evidence again is not spelt out. In the absence of a whistleblower or other complaint mechanism, one must assume that the Supervisory Authority would play an active role in procuring this evidence, perhaps flowing from the successful completion of an Article 46(2)(a) inquiry.

Interestingly, there is no mention of consequences should the FE fail to heed the warnings or alter its behaviour to comply with the law. Presumably, if the matter relates to tax law violation the tax authorities would investigate and impose sanctions independently. This assumption is supported both by Article 48(2), requiring the Supervisory Authority to keep the home tax authority abreast of any investigations and imposed outcomes, as well as by Article 48(3) which entitles a tax authority of any Member State to request documents or information on particular FEs from the registry and Supervisory Authority of the home Member State. In the absence, however, of either an early warning system to alert foreign tax authorities to an Article 46 investigation or evidence of suspicious FE activities in the host Member State, there may be little to prompt host tax authorities to exercise their rights under Article 48(3).

If the matter is unrelated to tax, short of seeking to wind up the FE or the dismissal of Board members, there seems to be little in the way of remedial action available to a Supervisory Authority unless such powers exist already in national law. Again, a simple amendment to include a whistleblower provision or other third-party complaint mechanism would greatly strengthen the enforceability and effectiveness of the proposed statute in this regard.

\subsubsection{Power to dismiss or seek dismissal of a Governing Board member}

One of the more powerful sanctions granted to the Supervisory Authority is the power to dismiss a member of the governing board or where provided for in national law to propose the dismissal to a competent court (Article 46(2)(d)). The power to dismiss must be exercised in accordance with the provisions of Article 28, which sets down the conditions for dismissal. These are namely:

- The member, based on his acts/omissions, is adjudged to be unfit to fulfil the duties of a board member;

- The member is found guilty by a court of financial impropriety;

- The member does not meet the admission requirements set out in the founding documents or the statutes of the FE;

- The member lacks full legal capacity or becomes either disqualified under the laws of any Member State or by way of judicial or administrative decision in any Member State from serving as a Board Member. 
A finding of member unfitness may arise from the findings of an Article 46(2)(a) inquiry or it could arise independently of this process under national law. The likelihood of a Supervisory Authority seeking member dismissal is, to a large extent, tied to the degree to which the Supervisory Authority plays an active role in the overall supervision of the foundation. Absence of a third-party complaint mechanism may hinder the effectiveness of this sanction. The final ground that may lead to dismissal (namely, disqualification under the laws of any Member State from serving as a Board Member either by way of judicial or administrative decision) highlights the need for good communication between Member State agencies (which extends beyond mere Member State supervisory authorities) and emphasises yet again the need for the Commission upon receipt of FE-related information to make it easily available to interested parties.

\subsubsection{Power to wind up or to seek the winding-up of the FE}

Finally, under Article 46(2)(e), the Supervisory Authority can decide to wind up an FE or to propose its winding-up to a competent court in accordance with Article 43(2). Two bases are provided for seeking the winding-up of a FE:

(a) Where the FE continuously violates its statutes, the Council Regulation or the applicable national law (Article 43(2)(b)); or

(b) Where the governing board itself has not sought to wind up the FE when any of the following three situations arise: (i) the purpose of the FE has been achieved or cannot be achieved; (ii) the time for which it has been set up has expired; or (iii) the FE has lost all of its assets (Article 43(2)(a)).

Prior to exercising this power, the Supervisory Authority must first grant the FE's governing board a right of hearing. A winding-up application is really the ultimate sanction and, as with most radical sanctions, its use is likely to be rare. The proposed Regulation is again light on detail as to when this power may be exercised. No guidance is given as to what constitutes a "continuous" violation in Article 43(2)(b). Clearly, this means more than once but how many times must the case against the FE be proven before the Supervisory Authority can act? Twice, trice, more? No indication is given as to the level of breach necessary to trigger such a winding-up petition, which brings us back to a policy question raised in Section 3-should such breaches take the form of malfeasance or can continuous evidence of operational inefficiency trigger winding-up proceedings under the EFS? Would, for instance, failure to file accounts and an annual report with either (or both) the registry and the Supervisory Authority in two or more consecutive years merit such an action or would an intermediate action (e.g. the 
appointment of an independent expert) or an intermediate sanction (e.g. a warning under Article 46(2)(c)) be more appropriate? Moreover, would failure to issue such a warning be a bar to seeking the winding-up of the FE?

A similar supervisory authority power to seek a winding-up can be found in a number of Member States' national laws. There is, however, little empirical evidence available as to its frequency of use by national authorities. Even recent studies of the powers of national supervisory authorities are more likely to discuss the theoretical availability of this sanction rather than discussing its practical use. ${ }^{49}$

\subsection{Effect of supervisory authority exercising powers}

Exercise by the Supervisory Authority of any Article 46(2) powers over an FE constitutes an effective veto on the FE transferring its registered office from its home Member State to another Member State (Article 36(3)) at least until the conclusion of any such actions initiated. This veto is copper-fastened by a further vetting process in Article 37, which requires that an FE wishing to move its registered home must first obtain a certificate from the "competent authority" of the home Member State verifying that none of the Article 36(3) "veto on transfer" situations arise. Establishing which authority is the relevant "competent authority" (a term used but not defined in the Regulation) and maintaining this information in a form easily accessible to host supervisory authorities may raise its own practical difficulties, an issue further discussed in Section 6.

\subsection{Cooperation amongst supervisory authorities}

Inter-state cooperation will be essential to the successful working of the EFS given the cross-border nature of the FE's activities (Article 6). This transnational element means that at any time there are at least two potentially interested supervisory authorities, namely the home Supervisory Authority (located in the Member State in which the FE has its registered office) and any other Supervisory Authorities (located in the host Member States in which the FE carries out its activities). The mandatory language used throughout Article 47, which deals with cooperation amongst supervisory authorities, requires that these bodies act reciprocally in the provision of relevant information to one

49 Hopt et al., n. 46, at 173. 
another on infringements or suspected infringements by the FE of its statutes, the Regulation or applicable national law.

The Supervisory Authority of a host Member State can request the Supervisory Authority of the home Member State to investigate suspected infringements by a particular FE. According to Article 47(3), upon receipt of such request the Home Supervisory Authority "shall investigate" (under Article 46) and "shall inform" the requesting Supervisory Authority of the conclusions which it draws from the information available to it and of any action taken. The effectiveness of this delegated investigation will depend greatly on the efficacy of existing national procedures for supervising national foundations.

Evidence to date indicates that existing levels of Member State scrutiny, oversight and proactive enforcement of national foundation laws are far from uniform. The root of this problem, as noted in Section 4.1.2, lies in the related issues of lack of Supervisory Authority capacity for such engagement or simply a lack of agency prioritisation of such scrutiny. Although the proposed Regulation mandates the home Supervisory Authority to act at the request of another Supervisory Authority, there does not appear to be any recourse for a frustrated host Member State authority if a home authority is slow to act or lacks capacity to see the matter through to fruition or in any other way fails to resolve the matter satisfactorily. The requesting Supervisory Authority can neither exercise the powers under Article 46 in relation to FEs registered in another Member State itself nor is there any mechanism of ultimate appeal to the Commission provided to resolve the matter. Absence of such a referral mechanism is a major shortcoming in the EFS proposal.

There is much to recommend a knowledge exchange network that would coordinate Member State supervisory activity and provide a platform for resolving any conflicts that could arise. A useful comparator in this instance may be the approach adopted in Regulation 1/2003 on the implementation of the rules on competition laid down in Articles 101 and 102 TFEU, which provides for the establishment of a European Competition Network (consisting of the competent Member State authorities and national courts and the European Commission) working closely together to resolve competition law issues. ${ }^{50}$ The network "provides a forum for national competition authorities and courts to coordinate the investigation, to cooperate, to exchange information, and to warrant legal consistency" in the enforcement of EU competition law. ${ }^{51}$ Acting as a central point of contact (since it is notified every time a new case is opened), the Commission

50 O.J. 2003 L $1 / 1$.

51 Wigger, A., Competition for Competitiveness: The Politics of the Transformation of the EU Competition Regime (Amsterdam: Vrije Universiteit, 2008-06-19), p. 327. 
provides national authorities with an accessible reservoir of information on the activities taken by other members of the network. ${ }^{52}$ At the same time, the Commission through its reserved power to intervene and withdraw a case from a national authority to protect the community interest has the ability to consolidate competition culture and mitigate the risks of less than stringent adherence by national authorities to the goal of undistorted competition. ${ }^{53}$ Inclusion of a similar mechanism could play a valuable role in the functioning of the EFS.

Although Regulation 1/2003 serves a very different purpose to the draft EFS Regulation, and both regulations start from very different positions, lessons learnt in the competition law regime could be applied to and further enhance the EFS scheme under the headings of transparency and accountability. It is clear from the proposed Regulation that knowledge of the requisite Supervisory Authority will be necessary not just for other such authorities but also for all Member State tax authorities. To facilitate greater ease of cooperation and transparency in this regard, there is a need for greater clarity as to the role of DG Internal Market and Services in overseeing the implementation of the Regulation and in acting as the repository for information relayed to it annually under Article 22. As keeper of information on designated national registries (Article 22(1)), designated supervisory authorities (Article 45(1)) and annual updates on the numbers of FEs registered and removed, the DG could play an important role in facilitating transparency. Maintenance of a website providing public access to some or all of this contact information (along the lines of the European Competition Network website) should thus be considered. The Commission also has the potential to play "honest broker" between supervisory authorities in a case in which the particular national procedure (or perhaps competent national authority) is ill equipped to deal in a timely fashion with the concerns of a fellow Member State Supervisory Authority under Article 47. Amending the EFS to make express provision for such enabling and reserve powers on the part of the Commission would strengthen the regulatory framework by developing an effective communication conduit between the Commission, the various supervisory authorities and the national tax authorities.

In their 2011 Joint Report on transparency and accountability of public benefit foundations, DAFNE and the EFC note that in some countries in which

52 The European Competition Network website is maintained by DG Competition and provides a one-stop-shop for accessing relevant information on each national competition authority along with publicly accessible information on actions taken by the various authorities in furtherance of European Competition law. See http://ec.europa.eu/competition/ecn/index_en. html (last accessed September 14, 2012).

53 Art. 11, Regulation No. 1/2003, supra n. 50. 
the position of the State Supervisory Authority is weak, one may find that private supervisory mechanisms (in the forms of a supervisory board or audit requirement) are mandatory. ${ }^{54}$ Such non-statutory regulation may compensate for the lack of proactive home Supervisory Authority oversight in a practical sense but given that these private enforcement mechanisms will fall outside the scope of both Articles 46 and 47, neighbouring supervisory authorities troubled by the activities of an FE may be left without an adequate response if the private proxy fails to deliver. This yet again emphasises the need for the Commission to have reserve powers to deal effectively with such situations.

\section{Annual reports, annual accounts and auditing obligations}

In terms of direct accountability, Article 34(2) requires the FE to prepare and submit annual accounts along with an annual activity report to both the competent national registry and the Supervisory Authority within 6 months of the financial year-end. This establishes a clear reporting framework for FEs, applicable in all Member States, and thus provides an initial accountability benchmark. The proposed Regulation is silent as to the roles of both agencies upon receipt of this data apart from tasking the national registry with compiling and supplying the Commission with FE statistics based on the reports received (Article 22(2)). Neither does the Regulation speak to the consequences for an FE of failing to file within the stipulated period or failing to file at all, raising questions as to enforceability of the new regime.

A number of Member States require foundations to submit copies of annual accounts and reports to supervisory authorities (e.g. France, Germany, Poland, England and Wales and Spain). ${ }^{55}$ This requirement, however, is not universal. The Netherlands has no reporting requirement for foundations (other than the preparation of annual accounts), ${ }^{56}$ whereas Austrian Foundation law requires only the filing of a narrative report on the foundation's activities. ${ }^{57}$ By contrast, pending the implementation of the long-awaited Charities Act 2009, unincorporated Irish foundations with an annual income of less than €100,000 are not obliged to report to any Supervisory Authority on an annual basis.

54 EFC/DAFNE Report, supra n. 27 at [3.3].

55 Hopt et al., n. 46, at 172.

56 Van der Ploeg, "Nonprofit Organisations in the Netherlands", in Hopt and Von Hippel (eds), Comparative Corporate Governance of Non-Profit Organizations (Cambridge, 2010), at 256-257.

57 Austrian Law on Federal Foundations and Funds 1974, s.14. 
Member States also differ in their deadlines for filing annual accounts and reports. Given this lack of uniformity, there have been calls to lengthen the proposed EFS submission period from 6 to 12 months. ${ }^{58}$ Denmark, ${ }^{59}$ France, ${ }^{60}$ and Hungary ${ }^{61}$ each currently impose a 6-month deadline. The submission period is even shorter in Luxembourg, which requires directors of foundations to publish the annual accounts in the Mémorial within 2 months of the closing of the accounts. ${ }^{62}$ In the UK, whereas public companies have 6 months to submit their accounts to Companies House after the end of each accounting reference period, ${ }^{63}$ the Charity Commission grants foundations formed as charitable companies a longer submission period of 10 months from the financial year-end. ${ }^{64}$ Notwithstanding this extended filing period, 39\% of charitable companies that filed late with the Charity Commission had made the earlier filing deadline of Companies House, prompting the Charity Commission to call for the introduction of late filing fines in line with the practice of Companies House. ${ }^{65}$

\subsection{Annual report}

The proposed Regulation provides that the FE's annual activity report must include, at minimum:

(a) information on the FE's activities;

(b) details on how the FE has promoted its public benefit purposes during the financial year;

(c) a list of the grants distributed, taking account of the right of privacy of the beneficiaries. $^{66}$

58 European Foundation Centre, Preliminary Legal Analysis of the European Commission proposal for a Council Regulation on the Statute for a European Foundation (FE), June 21, 2012b.

59 Danish Act on Non-Enterprise Foundations 1985, s. 2-3.

60 Art. 12[2], French model statutes nos. 1 and 2.

$\mathbf{6 1} \mathrm{http} / / /$ www.efc.be/programmes_services/resources/Documents/hungary.pdf.

62 http://www.efc.be/programmes_services/resources/Documents/luxembourg.pdf. Similarly, Slovenia imposes a 3-month deadline upon the year-end for foundations to submit their annual accounts to the authority competent for foundations (source: http://www.efc.be/programmes_services/resources/Documents/slovenia.pdf).

63 http://www.companieshouse.gov.uk/about/gbhtml/ca_gba3.shtml.

$64 \mathrm{http}$ ///www.cro.ie/ena/annual-return-filing.aspx (last accessed September 13, 2012).

65 Nicki May Young, "Commission needs to Toughen up on 'late filing' says Younger," Civil Society, September 26, 2012 available at http://www.civilsociety.co.uk/governance/news/content/13441/commission_needs_to_toughen_up_on_late_filing_says_younger (last accessed September 30, 2012).

66 EFS, Art. 34(3). 
National law can further expand upon these requirements. The emphasis on narrative or performance disclosure of the type required in (b) is in line with growing trends towards this type of impact accounting in the UK and the US at both a sector and a regulatory agency level. ${ }^{67}$ This type of reporting presents its own challenges. Since 2008, all charities in England and Wales must report on the manner of their achievement of public benefit purposes in the Trustees' Annual Report submitted to the Charity Commission. Lord Hodgson's Review of the Charities Act 2006 indicates that meeting this requirement has proved difficult in practice:

Research conducted by Sheffield Hallam University for the Charity Commission found that, among charities with income of over $£ 500,000$, only $25 \%$ fully met the requirement in their 2009/10 report (the first full year in which it was required). Among smaller organisations, that fell to $10 \%$ and in the smallest (£5,000-£25,000), $2 \% .^{68}$

The difficulty, according to the research lay "not in reporting what the charity had done or whom it intended to benefit, but rather how its action had benefitted the intended beneficiaries." 69 This difficulty may be compounded in practice for FEs, since they will make their annual reports to their home Supervisory Authority and registry; yet the actions undertaken will most likely be carried out in other Member States, making home authority verification of reports problematic.

Some stakeholders have also expressed concern over the proposed requirement for FEs to disclose the names of grantees in the Annual Activity Report. ${ }^{70}$ The argument made is that publicity may threaten supported civil rights projects' existence or beneficiary organisations in fragile political situations.

67 See Breen, The Disclosure Panacea: A Comparative Perspective on Charity Financial Reporting (2013) Voluntas 852. See also Jetty and Beattie (2008) Factors Influencing Narrative Disclosure by Large UK Charities: Interview Evidence. [online] Available at SSRN: http://ssrn. com/abstract=1308180 or http://dx.doi.org/10.2139/ssrn.1308180; New Philanthropy Capital, Principles of Good Impact Reporting for Charities and Social Enterprises (2012); In a US context see http://www.chartingimpact.org/ (last accessed March 25, 2013).

68 Hodgson, Trusted and Independent: Giving charity back to charities Review of the Charities Act 2006 (2012) at 4.9 available at http://www.cabinetoffice.gov.uk/sites/default/files/ resources/Review-of-the-Charities-Act-2006.pdf (last accessed September 13, 2012).

69 Hodgson, supra, n. 68, citing The Charity Commission/Sheffield Hallam University, Public Benefit Reporting by Charities: Report of a study undertaken by Sheffield Hallam University on behalf of the Charity Commission for England and Wales, June 2011 at 33.

70 See n. 58 supra, at [2.34]. 
Notwithstanding the validity of this concern, it would be wrong to grant all FEs blanket exemption from the grantee disclosure requirement. Publicity acts as a valuable safeguard by minimising the possibilities for a foundation to favour connected individuals or to cater to private needs. ${ }^{71}$ Beneficiary disclosure also sheds some light on the extent of an FE's charitable disbursement in a given year. When such information is provided alongside clear eligibility criteria for grant programmes, it allows potential applicants to rate themselves against successful beneficiaries. Article 34(3)(c) currently allows account to be taken of the privacy of beneficiaries as a ground for non-disclosure. The Commission could usefully clarify the intended scope of this exception and whether it might cover grants to entities in sensitive political situations.

\subsection{Annual accounts}

The proposed Regulation requires all FEs to "keep full and accurate records of all financial transactions” (Article 34(1)), a task initially befalling the governing board of the $\mathrm{FE},{ }^{72}$ but one that can be delegated to the FE's managing directors. ${ }^{73}$ The first reporting period for a registered FE would run from the date of its initial registration until the last day of the financial year, as specified in the FE's statutes. The Regulation provides no guidance on the format such accounts should take and the standard to which such accounts should be prepared. Yet, these are important matters. Given the pan-European nature of the FE, its credibility will largely depend upon the transparency and accountability of the organisation. Financial accounts are an important window on accountability. To serve well, such accounts must be accurate, reliable and (at least in a panEuropean context) comparable.

Achievement of these goals would demand adherence to a clear accounting standard, and at the very least, some general guidance as to the basis on which those accounts should be prepared (i.e. on a cash basis or an accrual basis). Given the relatively low capital threshold imposed upon the creation of an FE $(€ 25,000)$, there are likely to be large variations in the assets, revenue and annual turnover of foundations. In light of this, the omission of guidance on

71 See Mecking (2010) “Good and Not so Good Governance of Nonprofits: Germany," in Hopt and Von Hippel, supra n. 56, at p. 47.

72 Art. 29(1)(a) requires the Governing Board to take responsibility for the proper administration, management and conduct of the FE's activities.

73 Art. 30. 
accounting standards and thresholds from the draft Regulation is a missed opportunity to improve the existing level of foundation accountability.

The EFC/DAFNE Report on Accountability summarises well the current situation regarding foundation reporting. ${ }^{74}$ Noting the great differences that exist between Member States regarding the content and form of financial reports, the level of exactitude imposed in their preparation (e.g. whether an audit is required) and the extent to which they are publicly available, the Report concludes:

[W]hile overall foundations are required to account for their annual activities there is no identifiable trend in Europe as to what constitutes good practice with regard to reporting, and some gaps still exist. ${ }^{75}$

The omission of such good practice reporting standards in the EFS is a serious flaw. Inclusion of guidance on acceptable financial reporting standards would have contributed to the overall aim of the Regulation to create a regime in which public trust and credibility in FEs would be well founded. Availability of comparable accounts is essential for effective accountability and transparency and consistent with international moves towards globally accepted IFRS as well as being in line with the Commission's espoused policies on financial accounting. ${ }^{76}$

Arguably, lack of uniform financial reporting standards is not unique to non-profit accounting. Internationally, reform is underway to develop a single set of high-quality globally accepted IFRS. ${ }^{77}$ The EU is participating in this reform process and is working with the International Accounting Standards Board (IASB) to ensure broader adoption and adherence to IFRS and greater convergence with the US GAAP. To this end, in a for-profit context, the EU requires all listed companies to adhere to IFRS and further revisions to the European Accounting Directives promise greater IFRS alignment of the accounting standards for small and medium enterprises. ${ }^{78}$ Indeed, given this general policy direction and the fact that the very transparency and accountability upon which the credibility of the FE rests is rooted in financial integrity, the establishment of a new European legal structure presents the Commission with a

74 See supra n. 27.

75 Ibid, at 17.

76 European Commission Conference on Financial Reporting and Auditing - A time for change? Brussels (February 9-10, 2011).

77 http://www.ifrs.org/Use-around-the-world/Pages/Use-around-the-world.aspx (last accessed February 5, 2013).

78 Regulation 1126/2008 adopting certain international accounting standards in accordance with Regulation (EC) No. 1606/2002, O.J. 2008 L 320/1. 
valuable opportunity to develop a policy of uniform accounting standards, ${ }^{79}$ and it is disappointing that the Commission has not risen to the challenge in its draft EFS in this regard.

If the Commission were to take up the gauntlet of developing the requisite standards in a subsequent draft of the EFS, one would expect to see an accrual based accounting standard emerge. Under this accounting approach, revenues and expenses are matched to the time period in which they are earned or incurred, respectively. While it is more complex than cash based accounting, ${ }^{80}$ it provides much more meaningful financial reports in so far as it captures better the throughput of income and expenditure. ${ }^{81}$ For this reason, national GAAP rules are based upon accrual accounting procedures, and many jurisdictions require larger charitable organisations, in common with most for-profit entities, to prepare accounts on an accrual basis. The downside, apart from the complexity of accrual based accounting standards, is that they are designed to regulate for-profit business and thus do not take account of the particular challenges that arise in non-profit accounting. ${ }^{82}$ This has led to a need to develop additional Statements of Recommended Practice (SORPs) on a regional basis to address charitable accounting issues, resulting in varying accounting practices per jurisdiction. ${ }^{83}$ In the absence of the Commission remedying this deficit and revising the EFS to include minimum accounting standards, it follows that FEs will continue prepare their accounts according to local custom or convention of the home Member State. This will result in a myriad of approaches from the more ad hoc cash basis to accrual based accounts, influenced in some instances by the existence of a SORP (dependent on national regulations and the degree

\section{See supra n. 76.}

80 Because cash accounting financial statements have traditionally shown sources of cash receipts, the allocation of cash expenditure and provided a comparison of actual against budgeted expenditures, cash-based accounting systems can be less complex and certainly less costly to maintain - see Guthrie, "Accrual Accounting in the Australian Public Sector", (1998) Financial Accountability and Management, 14 (1) 1-19, at 5.

81 A noted shortfall of cash-based accounting is that while it may provide a clear picture of how much cash a foundation actually has, it may provide a misleading picture as to the overall sustainability of the foundation. See Cordery, "Cash-Based v Accrual Accounting: How should NFPs account for their business?” (2010) Chartered Accountants Journal of New Zealand, 89 (11) $58-9$.

82 The suitability of accrual based accounting has been challenged similarly in the context of public sector accounting. See Likierman, "Financial Reporting in the Public Sector" in Henley, Holtman, Chapman \& Hall (eds), Public Sector Accounting and Financial Control (1992) at 23 and Wynne, "Is the move to Accrual Based Accounting a Real Priority for Public Sector Accounting?” (2007) Public Fund Digest 25.

83 See Breen, supra n. 67. 
of enforcement applied) or not. This, in turn, will lead to difficulties in comparing FEs.

\subsection{Auditing requirements}

All FEs, regardless of size or annual turnover and regardless of which accounting method or standards they apply, will be required to file audited accounts (Article 34(5)). Upon registration with a competent national registry, the name of the FE's auditor(s) becomes a matter for disclosure (Article 23(1)(e)(iii)). The auditor in question must be approved to carry out statutory audits in accordance with the national rules adopted pursuant to Directive 2006/43/EC. ${ }^{84}$

Some stakeholders have argued in favour of the inclusion of an audit exemption. Certainly, in some Member States, the audit requirement is not universally applied. Thus, in the Netherlands, only the largest foundations are required to provide audited accounts ${ }^{85}$ and in Germany no auditing requirement exists for foundations. ${ }^{86}$ Institutional support exists for such a position. In its Opinion on the development of the EFS, the European and Economic Social Committee, supporting the motion, assumed that auditing would be required only of larger and not all foundations. ${ }^{87}$ More broadly, in his closing address to the European Commission Conference on Financial Reporting and Auditing, Director General of DG Internal Market, Jonathan Faull, rallied the Commission to work towards the development of harmonised exemption thresholds from statutory audit for small and medium sized enterprises, albeit in a for-profit context. $^{88}$

On the other hand, one could argue that given the public benefit nature of the FE, greater scrutiny should be required of all such foundations. In this case, "function" would triumph over "form" to justify the proposed Regulation's insistence upon a universal audit requirement. Indeed, a number of Member States follow such a practice with regard to national foundations. Thus, in France, all public utility foundations are subject to audit requirements. ${ }^{89}$ Private foundations in Norway, Austria and Sweden require external auditors, whereas in Finland, foundations must have a minimum of two auditors and two

84 O.J. 2006 L 157/87.

85 Van der Ploeg, supra n. 56, at 256.

86 Von Hippel, “Nonprofit Organizations in Germany”, in Hopt and von Hippel, supra n. 56, at 220.

87 O.J. $2011 \mathrm{C} 18 / 30$ at [3.2.2.11].

88 See http://ec.europa.eu/internal_market/accounting/docs/conference20110209/closing-faull_ en.pdf (last accessed September 21, 2012).

89 Deckert (2010), “Nonprofit Organizations in France”, in Hopt and von Hippel, supra n. 56, at 317. 
deputy auditors. ${ }^{90}$ In both the UK and Ireland, charities structured as public guarantee companies (which would include many foundations) are also required to file audited accounts. Larger charities, regardless of their legal structure, and must also provide audited accounts in line with a staggered annual turnover threshold.

It seems incongruous, however, to insist upon a universal audit requirement for foundations on the basis of the special need for transparency, while failing to mirror this level of oversight in the more fundamental requirement of standard preparation of accounts. Early indications in the European Parliament's Legal Affairs Committee draft interim report indicate support for allowing independent examination in lieu of audited accounts if certain financial thresholds are satisfied, ${ }^{91}$ but once more, no recommendations are made in relation to the development of standard accounting preparation procedures.

\subsection{Accounting requirements - the essence of disclosure}

What the proposed Regulation lacks in terms of specificity regarding the form of accounts it makes up for in its requirements for disclosure. The proposed Regulation provides that the annual accounts, once approved by the FE's Governing Board, must be disclosed along with the Auditor's Opinion and a copy of the annual activity report (Article 34(5)). Article 4 defines what is meant by disclosure; requiring that the relevant information must be disclosed in a way that is easily accessible to the public. "Easily accessible" might be construed in two senses, namely readiness of availability and comprehensibility.

\subsubsection{Readiness of availability}

Readiness of availability would suggest that an FE should post copies of its annual account and reports on its website and otherwise make this information available to interested parties. It would also be open to the national registry to make information received from FEs available to the public. To be sure, having financial records and annual reports readily available at a national registry level could provide a welcome one-stop-shop for interested parties, including host

90 Hopt et al, supra n. 46, at 206.

91 European Parliament Legal Affairs Committee, Draft Interim Report on the proposal for a Council regulation on the Statute for a European Foundation (FE), 2012/022 (APP), March 4, 2013, at 11. 
Member States, seeking further information about the activities of FEs. Such ready availability would amount to a change of practice in many jurisdictions in which such disclosure is not currently provided for by law or does not occur in practice.

The draft Regulation's requirements for FEs in this regard are a welcome development. They will raise the bar for some Member States, since national laws do not take a consistent line on disclosure. Disclosure of annual report and accounts is generally required in Belgium, the Czech Republic, Bulgaria, England and Wales, Estonia, Poland and Spain. ${ }^{92}$ In Hungary, a disclosure requirement exists for tax-exempt foundations. Disclosure to the public is less common in some civil law regimes such as France, Germany and Italy (with the exception of banking foundations to which different disclosure rules apply). ${ }^{93}$ Equally, Austria, Latvia and Cyprus do not have disclosure requirements. ${ }^{94}$

Even where disclosure requirements exist, this does not always result in ease of public access. Notwithstanding the general principle of public availability under Dutch law, the numerous exceptions to the disclosure requirement in the Netherlands mean that disclosure there is not guaranteed in practice. ${ }^{95}$ Similarly, statutory disclosure requirements in Ireland differ according to the legal structure of the foundation depending upon whether the entity is incorporated (in which case disclosure is mandated) or unincorporated (in which case it is not). ${ }^{96}$ While this situation is set to change with the coming into force of the Charities Act 2009, there will still exist an exemption from public disclosure for foundations set up as private charitable trusts which are not funded by public donation. ${ }^{97}$ In this context, it is disappointing that the European Parliament's Legal Affairs Committee draft amendments propose modifying the duty to disclose audited accounts, so that disclosure will occur in accordance with the rules of the Member State in which the FE has its registered offices. ${ }^{98}$

92 Hopt et al., supra n. 46, at 134-35.

93 Ibid.

94 EFC Country and Legal Profiles on Foundations available online at http://www.efc.be/ programmes_services/resources/Pages/Legal-and-fiscal-country-profiles.aspx (last accessed September 21, 2012).

95 See EFC Dutch Rapporteur at http://www.efc.be/programmes_services/resources/ Documents/netherlands.pdf (last accessed September 21, 2012).

96 Breen, supra, n. 67.

97 Irish Charities Act 2009, s.54.

98 See Committee on Legal Affairs, Amendments 1-24: Draft Report, Evelyn Regner, PE506.115v01-00, April 16, 2013b at 11. 


\subsubsection{Comprehensibility}

Disclosure in a manner that is easily accessible to the public would also require relevant information to be comprehensible. Comprehensibility is enhanced when there is clarity in financial reporting standards, particularly since the "public" in question may comprise donors from various Member States in addition to multiple Member States' agencies. Providing a common accounting standard for the new legal structure would make it easier to compare costs, revenues, fundraising/grant expenditure and executive remuneration of various FEs operating in different Member States.

\section{Final interpretative obstacles}

In considering the potential workability of the proposed EFS Regulation, four final issues require comment. As currently drafted, all four issues have the potential to undermine the prospects of the EFS working effectively. Although none are ultimately insurmountable obstacles, all would require amendment of the proposed Regulation, either by way of increased definitional clarity or by way of accommodation of legal concepts currently absent from the proposal. These issues relate to the differences in approach by common law and civil law countries to public benefit, the meaning of "competent authority", the need to tackle the risks of quasi-private enforcement of foundation law and existing opportunities to facilitate closer tax authority cooperation.

\subsection{Common law/civil law chasms}

\subsubsection{Definition of public benefit purposes}

The proposed Regulation adopts a distinctly civil law approach to its treatment of public benefit foundations; an approach that may cause difficulties for common law Member States. Article 5 defines "public benefit purpose" in an exhaustive fashion, which both excludes areas that are considered charitable at common law, e.g. the advancement of religion, and includes purposes that would not be charitable in some common law Member States. ${ }^{99}$ The current

99 Neither the advancement of human rights nor the advancement of amateur sport are deemed charitable in Ireland. Consumer protection is not generally considered a charitable 
list, while providing legal certainty, cannot be described as the lowest-commondenominator of acceptable purposes, which will cause problems for Member States so long as the automatic tax recognition provision remains part of the EFS.

As the ECNL Study revealed there is no standard definition of "public benefit" or "charitable" that enjoys recognition throughout the Union. For common law Member States (such as the UK and Ireland), the concept of "public benefit" is just one component part of a larger test for determining whether a foundation has charitable status (for both civil law and tax law purposes). Even as between common law Member States, full consensus on the applicable standards is lacking. ${ }^{100}$ In civil law countries, different interpretations of "public benefit" exist, resulting in large variations in the number of entities covered by the term. ${ }^{101}$ Reference to public benefit in a functional common law sense (as opposed to Article 5(3) list sense) occurs only briefly in the context of the FE's need to "serve the public interest at large."102 This requirement falls short of the public benefit concept not least, because it leaves open the door for a narrow or self-serving definition of the "public" that could result in private benefit accruing to a beneficiary group.

If the national test for charitable tax exemption demands more than proof of "public benefit purpose" status, as understood in Article 5, it is difficult to see how compliance solely with EFS provisions, as currently drafted, would guarantee the tax benefits outlined in paragraph 21 of the Regulation's Preamble $^{103}$ and in Article 49(3). It is thus of great interest that the draft amendments proposed by the European Parliament's Legal Affairs Committee in April 2013, if adopted, would see the tightening of the public benefit

purpose per se in either the UK or Ireland. While religion was omitted from the public benefit list to secure French support for the draft Regulation, it is noteworthy that the Parliament's Legal Affairs Committee has proposed the inclusion of "the promotion of religious dialogue" as a public benefit purpose in its recent amendments. See n. 98, at 4 .

100 See, for example, the difference of interpretation applied by Irish courts to the concept of public benefit in Re Cranston [1898] 1 IR 431 with that adopted by the English courts in Re Hummeltenberg [1923] 1 Ch 237.

101 ECNL Report, supra n. 30, at 12-13 (noting that "in Hungary, the total number of NPOs in 2006 was 58,000, out of which over 30,000-i.e. over 52\% - was a registered public benefit organisation. In other countries, of course, the proportion of PBOs is much lower (e.g. in Poland $-10 \%$ or Bulgaria - 20\%)...”.

102 Art 5(2), supra n. 12.

103 Paragraph 21, in providing that similar tax treatment should be afforded to the FE and its donors, states that "in all cases, this treatment should be applied without any need for the FE or its donors or beneficiaries to prove that the FE is equivalent to domestic public benefit purpose entities." 
requirement particularly in Article 5 of the proposal so that an FE would comprise not simply a separately constituted entity established for a public benefit purpose but rather one established exclusively for a public benefit purpose. ${ }^{104}$ Moreover, conscious of concerns already expressed at European Council level regarding the granting of automatic application of equal tax treatment to FEs, the Legal Affairs Committee has recommended the deletion of Articles 49 and 51 of the EFS, removal of which would limit the proposal to the status of a civil law instrument only. ${ }^{105}$

\subsubsection{The charitable trust concept}

A further conceptual chasm highlighted by the proposed Regulation is the exclusion of charitable trusts from the scope of the EFS. Trusts, and indeed charitable trusts, are alien concepts in many civil law jurisdictions. By their very nature, charitable trusts lack legal personality, an essential element for the formation of an FE. ${ }^{106}$ As such, the proposed Regulation does not make any provision for the conversion of existing charitable trusts into FEs.

Given that common law jurisdictions tend to play fast and loose with the use of the "foundation" label, many charitable foundations, established as trusts, currently operating on a cross-border basis or wishing to do so in the future will be unable to avail of the EFS if it is enacted in its current form. A search of the Charity Commission of England and Wales' Register of Charities reveals that there are in excess of 2,493 "foundations" with an income level above £25,000. A random sampling of these charities reveals that a significant number are established as trusts. The common law tendency to assimilate charitable trusts and foundations is further evidenced by the 2007 Report on Grant-making by UK trusts and Charities, which uses the terms "trust" and "foundation" interchangeably, concentrating on the grant-making nature of the charity rather than the presence or absence of legal personality. ${ }^{107}$ Building upon this report, the

104 See Legal Affairs Committee, Draft Report Amendments, supra n. 98, at 3, making recommendations to amend the current text of Article 5(1) EFS. This proposal received a majority endorsement from the European Parliament on July 2, 2013. See n. 110, infra.

105 Legal Affairs Committee, Draft Report Amendments, supra n. 98, at 14-15 (recommending deletion of Article 49 concerning tax treatment of donors to the FE and of Article 51, concerning tax treatment of beneficiaries of an FE.

106 See Arts 2(5) and 12 of the EFS.

107 See n. 24 supra, at 3. 
European Feasibility Study on the EFS more recently included grant-making trusts within its working definition of foundation, ${ }^{108}$ a step the Commission did not take in its draft proposal.

This exclusion of a conversion option for trusts in the draft EFS will make it difficult for charitable trusts to easily avail of the advantages offered by the FE structure. The only option open for a trust would be to establish a new FE to which it could then transfer trust assets. Despite calls for a conversion option to be introduced, ${ }^{109}$ the European Parliament's Legal Affairs Committee did not make any recommendations regarding extension of the FE to trusts in its draft interim report.

\subsection{The meaning of "competent authority"}

As the EFC profiles demonstrate, Member States adopt a flexible approach to what constitutes the relevant "Supervisory Authority" for the supervision of foundations. Sometimes, the Supervisory Authority comprises a public body (such as a ministry or government department); other times, an independent statutory body may be the relevant agency (e.g. the Charity Commission for England and Wales), and in many jurisdictions, the relevant Supervisory Authority may be a combination of one of these two options with a national court. Thus, at any time in a given Member State, there may be a number of players capable of wearing the "Supervisory Authority" cap.

Chapter VII of the EFS, dealing with the role, powers and duties of the Supervisory Authority interprets supervisory authority as a single national agency. ${ }^{110}$ By contrast, Chapter IV of the Regulation is more open to a supervisory body comprising more than one agency. Most notable in this regard are the articles dealing with cross-border mergers of FEs, conversion to an FE and the procedure governing the transfer of an FE's registered office to another Member State in which reference is made to the powers of the "competent authority". ${ }^{111}$ The confusion inherent here reinforces the need for the creation of European Supervisory Authority Enforcement network maintained centrally

108 See n. 1, supra, at 14-15.

109 John Riches, Society of Trust and Estate Practitioners Submission on the European Foundation Statute to the European Parliament, November 26, 2012.

110 The European Parliament resolution of 2 July 2013 on the proposal for a Council regulation on the Statute for a European Foundation (FE) (COM(2012)0035-2012/0022(APP)) included amongst its proposals that a Member State should be able to designate one or more authorities to be responsible for the effective supervision of FEs.

111 Articles 15, 16, 18, and 37, supra n. 12. 
(preferably by the Commission) which identifies and facilitates contact between the appropriate Member State bodies tasked with a role in the regulation of FEs. Greater clarity as to what "competent authority" under the Regulation means and allowing one or more national agencies to comprise the required supervisory authority would improve the proposal.

\subsection{From supervisory board and private enforcement to supervisory authorities and public powers}

Article 31 provides that the statutes of the FE "may provide for a supervisory board and other bodies." As noted by the 2011 EFC/DAFNE Report, in some countries in which the requisite Supervisory Authority is comparatively weak, there may be mandatory requirements for other forms of external private scrutiny or oversight. ${ }^{112}$ These mechanisms may include outsourcing scrutiny to a supervisory board or requiring external audits. Nationally, these external mechanisms act as a proxy for the weak supervisory public authority. Article 31 facilitates such additional (or, in some cases, alternative) scrutiny.

It is unclear whether the supervisory authority cooperative powers envisaged by Article 47 will cover such a situation. In other words, if effective national supervision is outsourced from a public authority to a private enforcement mechanism, how will an affected Supervisory Authority in another Member State exercise its rights to demand an investigation or to be kept informed of investigative developments or outcomes? There appears to be no mechanism to cover such exigencies, and the absence of a central source of Commission authority in this regard may be crucial in such instances.

\subsection{An opportunity for greater tax authority cooperation}

Home supervisory authorities are only mandated to directly inform the tax authorities of their own Member State when undertaking Article 46 investigations. There is no requirement to inform other tax agencies notwithstanding that host Member States' tax treatment of an FE may also be affected. Although Article 48(3) entitles any Member State tax authority to request a home Supervisory Authority to make available documents or information concerning an FE, Article 48's asymmetrical information approach deprives foreign tax authorities of the alarm bell to prompt them into action. In the same way that

112 See EFC/DAFNE Report, supra n. 27. 
a foreign tax authority request regarding an FE might prompt a home Supervisory Authority to take a closer look at the FE, there should be a reciprocal early warning mechanism allowing a home Supervisory Authority to alert all interested tax authorities when action is taken under Article 46.

The creation of European Supervisory Authority Enforcement network could provide a convenient platform under Article 47(2) for sharing such information broadly amongst supervisory authorities, enabling them to then filter this information down to the relevant host tax authorities in affected jurisdictions, thereby closing the information loop. Moreover, incorporating reference to the European Directive on Administrative Cooperation in the Field of Taxation would further facilitate information exchanges between tax authorities in relation to FE conduct. ${ }^{113}$ Whether the tax element of the proposal will make it to the final Regulation now remains to be seen in light of European Parliament's endorsement of the interim recommendations of the Legal Affairs Committee to delete these contentious provisions to better ensure the required unanimous approval of the European Council in light of the well-known divisions in the Council on this issue. ${ }^{114}$

\section{Conclusions}

The recent European Parliament resolution in favour of the $\mathrm{EFS}^{115}$ sees the Commission's proposal for the EFS along with some 34 proposed modifications by the European Parliament go forward to the European Council for its ultimate deliberation and required unanimous approval.

Overall, the Commission's focus on disclosure and accountability in the EFS is to be welcomed. Legislative compromise is inevitable when operating in an area governed by non-harmonised national provisions and the proposal goes some way towards providing minimum reporting standards and minimum supervisory powers. Effective implementation, not to mention the avoidance of forum shopping, will be dependent upon a workable and shared concept of the rationale for accountability and a comparable understanding of the role of Member State regulation in this context. This goal will itself only be achievable if information on FEs is comprehensible and comparable.

113 2011/16/EU of 15 February 2011, OJ L 64/1.

114 See Legal Affairs Committee, Draft Interim Report, n. 91, at Preamble L. See also Preamble U of European Parliament resolution of 2 July 2013 on the proposal for a Council regulation on the Statute for a European Foundation (FE) (COM(2012)0035-2012/0022(APP)).

115 See n. 110 supra. 
Scope remains, however, for further improvement of the original proposal improvements that may need to go further than those currently proposed by the Parliament's Legal Affairs Committee. This article has attempted to identify a number of areas in which revision, amendment or insertion of new powers would enhance the draft Regulation. There is room for greater clarity in the draft Regulation regarding the trigger for supervisory oversight, that is, whether a matter falls under the terms of the Statute or to national law for determination. Similarly, a more cogent exposition of the Commission's powers and responsibilities under the Statute would aid the workability of the Statute. To this end, the Commission should be given an express reserve power to intervene in the case where a Member State Supervisory Authority is either unable or unwilling to fulfil its role under Article 46. Secondly, the creation of a European network for information exchange between supervisory authorities, tax authorities and the Commission would further consolidate the regulatory framework allowing greater ease of communication and helping to prevent the creation of diverse regimes which could give rise to forum shopping. A third step in enhancing any such framework would be the creation of an information portal identifying all relevant agencies involved and enabling a one-stop shop for the filing of all relevant reports and accounts, Article 47 interventions or FE requests for mergers or change of registered office. The European Parliament's proposal to allow a Member State to authorise more than one agency as its supervisory authority is to be welcomed but serves to emphasise the need for a digital portal linking all such authorities to one another.

On the enforcement front, the introduction of a whistleblower mechanism along with a separate third-party complaint mechanism would assist supervisory authorities in their oversight roles by creating a formal channel for the communication of grievances, on the one hand, from employees or FE beneficiaries, and on the other hand, from agencies or the general public in host countries in which the FE is active.

This article began by stressing the importance of accountability and transparency to the workability of the EFS. The Commission is to be commended for its efforts to introduce minimum supervisory powers and levels of oversight, but such oversight can only be effective if consistent and comparable reporting standards are in place. There is an urgent need for the Council to take up the opportunity presented by the introduction of the FE to embed in the EFS minimum best practice accounting reporting standards. Inclusion of such reporting standards would fit with broader moves towards standardised accounts advanced by the IASB and supported by the EU. Given the intended panEuropean outlook of the FE, the failure to consider minimum accounting and reporting standards at this time would be ill-advised.

It is likely that the European Council's deliberations will divide along civil law jurisdiction/common law jurisdiction lines on certain issues. Sticking points for 
common law Member States are likely to arise in relation to the proposed definition of public benefit underlying the FE, which falls far short of the common law definition of charity. The English House of Commons Select Committee, charged with scrutinising the EFS proposal, has already nailed its colours to the mast in this regard, fearing that non-alignment between traditional charitable purposes and those "public benefit" FE purposes will give rise to a two-tier system which would force the UK government to accept as charitable entities meeting the European definition but not satisfying the UK definition. ${ }^{116}$ Referring specifically to the interpretation of "public benefit" in the European definition, the Select Committee noted that this was "an equally difficult issue as in the UK there are several hundred years of case law giving meaning to the term "public benefit" and, in the European definition, what is meant by "public benefit" will be open to wide interpretation, or would be based on inconsistent interpretations under different national laws." ${ }^{117}$ The UK's objections alone, if unmet, would act as veto on Council approval of the draft Regulation.

Exclusion of a conversion option for charitable trusts in the EFS will also limit the number of common law entities able to avail of the FE in a user-friendly fashion. Greater alignment of the meaning of public benefit with the common law definition and some accommodation of charitable trusts within the EFS would open up the potential for the Statute's use to a much wider constituency while simultaneously reducing the fears of common law jurisdictions that the passing of such a regulation would discriminate against domestic charities.

It remains likely, however, that the most controversial issue for consideration by the Council will concern the EFS provision for automatic tax equivalency in every Member State. A brief review of the scrutiny reports filed to date by national parliaments indicates that Germany, Ireland and the UK have raised fundamental objections to the tax elements of the EFS proposal, which if maintained, will prevent the Council's passing of the regulation in its current form. ${ }^{118}$ Acknowledging the steadfast resistance of a number of Member States in this regard, the European Parliament resolution supporting the EFS has proposed the axing of the tax element entirely in favour of the EFS proposal proceeding solely on a civil law basis. ${ }^{119}$ While adoption of this recommendation will ensure less resistance to the proposal's passing at Council level, it may very well reduce the

116 House of Commons, "European Scrutiny Committee, Eight Report of Session 2013-14-draft regulation on the European Foundation Statute, July 3, 2013.” Available at http://www.publications. parliament.uk/pa/cm201314/cmselect/cmeuleg/83-viii/8302.htm (last accessed August 1, 2013).

117 Ibid.

118 See the reports of the national parliaments at http://www.ipex.eu/IPEXL-WEB/dossier/ dossier.do? code=APP\&year=2012\&number=0022\&appLng=EN (last accessed August 1, 2013). 119 See n. 110, supra. 
attractiveness of the entity to the foundation sector and the ultimate take-up of the FE.

The name of the game will be compromise. To this end, amendments suggested in this article seek simultaneously to support the EFS' laudable objective of facilitating European philanthropy while going some way towards creating a stronger governance framework for European charitable activity. Whether a critical mass of foundations will be willing to subject themselves to such proposed scrutiny in the absence of automatic tax equivalency is another question. For the time being, the jury must remain out on the eventual form of the long-anticipated FE, and one must await the outcome of the Council's deliberations to see whether the overall objective sought by foundations and donors alike - the creation of a single market for charitable giving within the $\mathrm{EU}$ - is attainable in practice.

\section{References}

Baelz, K., and T. Baldwin. 2002. "The End of the Real Seat Theory (Sitztheorie): The European Court of Justice Decision in Ueberseering of 5 November 2002 and its Impact on German and European Company Law." German Law Journal 3. Accessed May 28, 2013. http://www. germanlawjournal.com/index.php?pagelD=11\&artID=214

Breen, 0. 2008. "EU Regulation of Charitable Organizations: The Politics of Legally Enabling Civil Society." International Journal for Not-for-Profit Law 10:50-78.

Breen, 0. 2013. "The Disclosure Panacea: A Comparative Perspective on Charity Financial Reporting." Voluntas 24:852-80.

Cordery, C. 2010. "Cash-Based V Accrual Accounting: How Should NFPs Account for Their Business?” Chartered Accountants Journal of New Zealand 89:58-59.

Deckert, K. 2010. "Nonprofit Organizations in France." In Comparative Corporate Governance of Non-Profit Organizations, edited by K.Hopt, and T. Von Hippel, 265-324. Cambridge: Cambridge University Press.

European Commission. 2005. Communication "The Prevention of and Fight against Terrorist Financing through Enhanced National Level Coordination and Greater Transparency of the Non-profit Sector: Recommendations for Member States and a Framework for a Code of Conduct for NPOs to Enhance Transparency and Accountability in the Non-profit Sector to Prevent Terrorist Financing and Other Types of Criminal Abuse." COM (2005) 620 final

European Commission, DG for Internal Market and Services. 2006. Report on Consultation and Hearing on Future Priorities for the Action Plan on Modernising Company Law and Enhancing Corporate Governance in the European Union. Accessed March 21, 2013. http://ec.europa.eu/internal_market/company/docs/consultation/final_report_en.pdf European Commission. 2010. "The Application of Council Regulation 2157/2001 of 8 October 2001 on the Statute for a European Company (SE), COM(2010) 676 final. 
European Commission. 2011. "Conference on Financial Reporting and Auditing - A Time for Change?” Brussels, February 9-10, 2011.

European Commission. 2013. "Public Consultation on the Cross-border Transfers of Registered Offices of Companies, January 14, 2013.” Accessed March 25, 2013. http://ec.europa.eu/ internal_market/consultations/2013/seat-transfer/index_en.htm

European Foundation Centre. 2007. "18th Annual General Assembly (AGA) and Conference, Why is a European Statute for Foundations Needed?" Madrid, June 1st-3rd 2007.

European Foundation Centre. 2012a. "It's Time for a European Statute." Accessed March 21, 2013. http://www.efc.be/programmes_services/resources/Documents/

EFS_brochure_2012_FINAL.pdf

European Foundation Centre. 2012b. "Preliminary Legal Analysis of the European Commission proposal for a Council Regulation on the Statute for a European Foundation (FE), June 21, 2012." Belgium: European Foundation Centre.

European Foundation Centre (EFC) and Donors and Foundations Networks in Europe (DAFNE). 2011. Exploring Transparency and Accountability Regulation of Public-Benefit Foundations in Europe. Accessed August 14, 2013. http://ecnl.org/dindocuments/371_EFC\% 20Accountability\%20Study.pdf.

European Parliament. Resolution on the proposal for a Council regulation on the Statute for a European Foundation (FE) (COM(2012)0035-2012/0022(APP), July 2, 2013.

European Parliament Committee on Legal Affairs. 2013a. Draft Interim Report on the proposal for a Council regulation on the Statute for a European Foundation (FE) (COM (2012)0035C7-0000/2013-2012/022(APP), March 4, 2013.

European Parliament Committee on Legal Affairs. 2013b. Amendments 1-24-Draft Report Statute for a European Foundation (FE), April 16, 2013.

Guthrie, J. 1998. "Accrual Accounting in the Australian Public Sector." Financial Accountability and Management 14:1-19, at 5.

Hammer-Jespersen, L. 2012. "The FE in light of the development of European Company Law: lessons from the SE, SCE and SPE”, presented at ERA, A New Legal form for European Philanthropy: The Commission's Proposal for a European Foundation (FE) Statute, Brussels, October 30-31, 2012.

Hodgson. 2012. "Trusted and Independent: Giving charity back to charities Review of the Charities Act 2006." Accessed September 13, 2012. http://www.cabinetoffice.gov.uk/ sites/default/files/resources/Review-of-the-Charities-Act-2006.pdf

Hopt, K., and T. Von Hippel, eds. 2010. Comparative Corporate Governance of Non-Profit Organizations. Cambridge: Cambridge University Press.

Hopt, K., R. Walz, T. von Hippel, and V. Then , eds. 2006. The European Foundation: A New Legal Approach. Cambridge: Cambridge University Press.

Matrix Insight. 2008. Study to Assess the Extent of Abuse of Non-Profit Organisations for Financial Criminal Purposes at EU Level, April 3, 2008. Accessed May 28, 2013. http:// ec.europa.eu/home-affairs/doc_centre/terrorism/docs/study_abuse_non_profit_orgs_ for_financial_criminal_purposes_avril09.pdf

Jetty, J., and V. Beattie. 2008. "Factors Influencing Narrative Disclosure by Large UK Charities: Interview Evidence.” [online]. Accessed August 14, 2013. http://ssrn.com/ abstract=1308180 or http://dx.doi.org/10.2139/ssrn.1308180.

Liberatore, F. 2012. “Tax Aspects of the Commission's Proposal for a European Foundation Statute," presented at ERA, A New Legal Form for European Philanthropy: The Commission's Proposal for a European Foundation (FE) Statute, Brussels, October 30-31, 2012. 
Likierman, A. 1992. "Financial Reporting in the Public Sector." In Public Sector Accounting and Financial Control, edited by H.Henley, 23. London: Chapman \& Hall.

MacDonald, N., and L.Tayart de Borms, eds. 2008. Philanthropy in Europe: A Rich Past, a Promising Future. London: Alliance Publishing Trust.

Mecking, C. 2010. "Good and Not so Good Governance of Nonprofits: factual observations from foundations in Germany." In Comparative Corporate Governance of Non-Profit Organizations, edited by K.Hopt and T. Von Hippel, 39-59. Cambridge: Cambridge University Press.

New Philanthropy Capital. 2012. Principles of Good Impact Reporting for Charities and Social Enterprises. Accessed August 14, 2013. http://bit.ly/15Djpbw

Salole, G. 2008. “Why Is the European Foundation Statute Needed?" International Journal for Not-for-Profit Law 11:75-84.

University of Heidelberg, Centre for Social Investment. 2009. "Feasibility Study on a European Foundation Statute - Final Report.” Accessed March 11, 2013. http://ec.europa.eu/internal_market/company/docs/eufoundation/feasibilitystudy_en.pdf

Van der Ploeg, R. 2010. “Nonprofit Organisations in the Netherlands." In Comparative Corporate Governance of Non-Profit Organizations, edited by K.Hopt and T. Von Hippel, 228-264. Cambridge: Cambridge University Press.

Wigger, A. 2008. Competition for Competitiveness: The Politics of the Transformation of the EU Competition Regime. Amsterdam: Vrije Universiteit.

Wynne, A. 2007. "Is the Move to Accrual Based Accounting a Real Priority for Public Sector Accounting?" Public Fund Digest 25-38.

Young, N. 2012 "Commission needs to Toughen up on 'late filing' says Younger." Civil Society, September 26, 2012. Accessed September 30, 2012. http://www.civilsociety.co.uk/ governance/news/content/13441/commission_needs_to_toughen_up_on_late_ filing_says_younger

European Centre for Not-for-Profit Law [ECNL]. 2009. "Study on the Recent Public and Self-Regulatory Initiatives Improving Transparency and Accountability of Non-Profit Organisations in the European Union.” Accessed May 28, 2013. http://ecnl.org/dindocuments/306_ECNL\%20Accountability\%20Study_published\%20on\%20DG\%20JLS.pdf 
